\title{
High level production of tyrosinase in recombinant Escherichia coli
}

\author{
Qun Ren*, Bernhard Henes, Michael Fairhead and Linda Thöny-Meyer
}

\begin{abstract}
Background: Tyrosinase is a bifunctional enzyme that catalyzes both the hydroxylation of monophenols to odiphenols (monophenolase activity) and the subsequent oxidation of the diphenols to o-quinones (diphenolase activity). Due to the potential applications of tyrosinase in biotechnology, in particular in biocatalysis and for biosensors, it is desirable to develop a suitable low-cost process for efficient production of this enzyme. So far, the best production yield reported for tyrosinase was about $1 \mathrm{~g} \mathrm{~L}^{-1}$, which was achieved by cultivating the filamentous fungus Trichoderma reesei for 6 days.

Results: In this work, tyrosinase from Verrucomicrobium spinosum was expressed in Escherichia coli and its production was studied in both batch and fed-batch cultivations. Effects of various key cultivation parameters on tyrosinase production were first examined in batch cultures to identify optimal conditions. It was found that a culture temperature of $32^{\circ} \mathrm{C}$ and induction at the late growth stage were favorable, leading to a highest tyrosinase activity of $0.76 \mathrm{U} \mathrm{mL}^{-1}$. The fed-batch process was performed by using an exponential feeding strategy to achieve high cell density. With the fed-batch process, a final biomass concentration of $37 \mathrm{~g} \mathrm{~L}^{-1}$ (based on optical density) and a tyrosinase activity of $13 \mathrm{U} \mathrm{mL}^{-1}$ were obtained in 28 hours, leading to a yield of active tyrosinase of about $3 \mathrm{~g} \mathrm{~L}^{-1}$. The highest overall volumetric productivity of $103 \mathrm{mg}$ of active tyrosinase per liter and hour (corresponding to $464 \mathrm{mU} \mathrm{L}^{-1} \mathrm{~h}^{-1}$ ) was determined, which is approximately 15 times higher than that obtained in batch cultures.

Conclusions: We have successfully expressed and produced gram quantities per liter of active tyrosinase in recombinant $E$. coli by optimizing the expression conditions and fed-batch cultivation strategy. Exponential feed of substrate helped to prolong the exponential phase of growth, to reduce the fermentation time and thus the cost. A specific tyrosinase production rate of $103 \mathrm{mg} \mathrm{L}^{-1} \mathrm{~h}^{-1}$ and a maximum volumetric activity of $464 \mathrm{mU} \mathrm{L}^{-1} \mathrm{~h}^{-1}$ were achieved in this study. These levels have not been reported previously.
\end{abstract}

Keywords: Tyrosinase, Recombinant protein production, High cell density, Fed batch culture, Bioprocess engineering, Exponential feeding

\section{Background}

Tyrosinase is a bifunctional enzyme that catalyzes both the hydroxylation of monophenols to $o$-diphenols (monophenolase activity) and the subsequent oxidation of the diphenols to $o$-quinones (diphenolase activity) [1]. Tyrosinase is essential for many living organisms to carry out various functions, including melanin biosynthesis as defense against the harmful effects of UV light [2-4]. In plants, it is required for the biosynthesis of phenolic polymers such as lignin, flavinoids, and tannins [5]. Tyrosinases also play an important role in the regulation

\footnotetext{
* Correspondence: qun.ren@empa.ch

Laboratory for Biomaterials, Swiss Federal Laboratories for Materials Science and Technology (Empa), Lerchenfeldstrasse 5, CH-9014 St, Gallen, Switzerland
}

of the oxidation-reduction potential of cell respiration and in wound healing in plants $[6,7]$.

Due to the ability of tyrosinases to react with phenols, these enzymes have been proposed for the uses in a variety of biotechnological, biosensor and biocatalysis applications $[1,8,9]$. For example, tyrosinases can be applied in detoxification of phenol-containing wastewater and contaminant soils [10], synthesis of L-3,4dihydroxyphenylalanine (L-DOPA), one of the preferred drugs for the treatment of Parkinson's disease [11], or as additives in food processes due to their cross-linking abilities [12,13]. Tailoring polymers, e.g. grafting of silk proteins onto chitosan via tyrosinase reactions have also been reported $[14,15]$. Immobilized tyrosinase has 
been investigated as an electrochemical biosensor for a range of phenolic compounds [16]. The enzyme can react with exposed tyrosyl side chains in polypeptides, and the reactive quinones formed allow for proteinprotein cross-linking [17-21].

Tyrosinases have been isolated and purified from various sources such as animals, plants, fungi, and bacteria $[2,22-25]$. The commercial production of tyrosinase is mostly reported from the common mushroom Agaricus bisporus. Extensive research has been carried out by using this mushroom tyrosinase because of its commercial availability. However, the use of tyrosinase from this source is problematic as the enzyme exhibits relatively low solvent and temperature stability, as compared to some bacterial tyrosinases [26-28]. Moreover, commercial tyrosinases are typically contaminated with other enzymes for example different isoforms, resulting in preparations of variable quality and activity [29]. Almost all reported tyrosinase-producing microbial (both fungal and bacterial) strains also produce other polyphenol oxidases such as peroxidase and laccase [30]. The presence of laccase and peroxidase along with tyrosinase imposes serious problems for commercial usage [31]. All these enzymes can use tyrosine as substrate but produce different products, resulting in reduced yield as well as increased cost for the downstream process. Recently, it was reported that a new Actinomycetes isolate produced only tyrosinase and did not exhibit peroxidase or laccase activities [30]. The production yield of tyrosinase was about $4.8 \mathrm{U} \mathrm{mL}^{-1}$ after $48 \mathrm{~h}$ incubation, which is still far too low to be applied for commercial purposes.

The recombinant production of tyrosinases becomes an attractive alternative to obtain large amounts of protein. Recombinant strains offer the possibility of a higher protein production level, better growth, and consequently, an improved productivity when compared to nonrecombinant production systems. However, tyrosinases appear to be difficult to express in recombinant hosts and only a few examples have been reported. The human tyrosinase has been expressed mostly as insoluble protein in inclusion bodies in Escherichia coli [32,33]. Tyrosinase from Pycnoporus sanguineus was expressed in Aspergillus niger [34], and the Streptomyces castaneoglobisporus tyrosinase was expressed in a complex with its "caddy" protein, ORF378, in E. coli [35]. Tyrosinase production has also been reported for the filamentous fungus Trichoderma reesei [36]. Overexpression of the tyrosinase gene allowed the native host $T$. reese $i$ to produce about $1 \mathrm{~g} \mathrm{~L}^{-1}$ tyrosinase in laboratory-scale batch fermentation after 6 days of cultivation [36]. Since growth of filamentous fungi is slow compared with most single-cell microorganisms, Pichia pastoris carrying the tyrosinase gene of $T$. reesei was tested and yielded $24 \mathrm{mg} \mathrm{L}^{-1}$ active recombinant tyrosinase in 3 days [37]. The E. coli recombinant was also used as host to produce tyrosinase from Streptomyces $s p$. REN-21, and $54 \mathrm{mg} \mathrm{L}^{-1}$ of the enzyme were obtained in the cytoplasm after $16 \mathrm{~h}$ incubation [26]. Recently, we have overexpressed and characterized the tyrosinase from Verrucomicrobium spinosum in E. coli [38]. However, even though the yield of this enzyme $\left(150 \mathrm{mg} \mathrm{L}^{-1}\right)$ was higher than those reported from other bacterial tyrosinases (unpublished data), we considered this yield could be further improved.

$E$. coli is commonly used as host for the rapid and economical production of recombinant proteins. Different cultivation techniques have been developed to increase the final biomass concentration $[39,40]$. However, highlevel production of functional proteins in $E$. coli may not be a routine matter and is sometimes challenging. Not every protein can be produced efficiently due to the unique structural features of the protein, its folding pathways and its degradation by host cell proteases [41]. Since useful recombinant proteins have to be biologically active, the objectives for production should include not only maximization of the amount of recombinant protein, but also of total enzyme activity.

The current work is based on the successful cloning of the tyrosinase gene from $V$. spinosum in $E$. coli and its purification and characterization [38]. The objective of this work was to develop a suitable strategy for efficient production of active tyrosinase in $E$. coli. The effect of temperature, inducer isopropyl-beta-Dthiogalactopyranosides (IPTG) concentrations and the starting time of induction in different operation modes (batch and fed-batch) were investigated. About $3 \mathrm{~g} \mathrm{~L}^{-1}$ active tyrosinase were obtained after 28 hours of incubation under the developed conditions. To our knowledge, this is the best yield and productivity ever reported for recombinant tyrosinase.

\section{Results and discussion}

\section{Production of tyrosinase in batch culture}

In order to establish an efficient production process for tyrosinase, preliminary optimization studies were performed in shake flasks. This allowed the selection of the best production host, growth temperature, time for induction and inducer concentration by using conventional methodology with changing one variable at a time.

\section{Influence of different host strains on tyrosinase production}

To reach efficient tyrosinase production, cells with high growth rate, high maximum biomass and high level tyrosinase activity are desired. However, overproduction of a protein often hinders the growth of bacterial cells and vice versa [42]. Thus, it is plausible to let the cells grow to a high cell density, and then induce expression of the relevant gene so that the protein of interest will be 
produced. In this study, E. coli DH5 $\alpha$, JM109 and BLR were transformed with pMFvpt which contains the gene encoding the cytoplasmic full-length tyrosinase $(53.5 \mathrm{kDa})$ of Verrucomicrobium spinosum [38]. The obtained recombinants were cultivated in shake flasks at $37^{\circ} \mathrm{C}$ and $150 \mathrm{rpm}$, and induced with $1 \mathrm{mM}$ IPTG at the early exponential growth phase $\left(\mathrm{OD}_{600} \approx 0.6\right)$. The cultivations were continued for $24 \mathrm{~h}$ and samples were taken periodically for measurement of cell density and tyrosinase activity. The results are summarized in Table 1. Although the DH5 $\alpha$ recombinant exhibited the highest tyrosinase production, the growth rate was more than 2 fold lower than that obtained with two other tested hosts. Furthermore, the expression of the tyrosinase gene could not be controlled in recombinant DH $5 \alpha$ because DH5 $\alpha$ does not have the repressor protein $\mathrm{LaCl}^{\mathrm{q}}$ and enables constitutive expression of tyrosinase gene from the T5 promoter / lac operator element in pMFvpt. BLR exhibited uncontrolled expression and very low activity of tyrosinase. By contrast, the JM109 recombinant showed controlled expression due to the presence of the $\mathrm{LacI}^{\mathrm{q}}$ repressor, even though the total tyrosinase production was lower than that in DH5 $\alpha$. Furthermore, the JM109 recombinant exhibited a high growth rate of $0.6 \mathrm{~h}^{-1}$. In order to reach high cell density, high growth rate and controlled production of the relevant protein are desired. Thus, in this study JM109 recombinant was chosen for further investigations.

\section{Influence of oxygen supply on tyrosinase production}

To investigate the influence of oxygen on tyrosinase production, experiments were conducted by comparing the cultures in baffled and non-baffled shake flasks. It was found that the total tyrosinase activity increased with an increase of cell density (Figure 1). Compared with the non-baffled culture, the baffled culture led to a higher final cell density and consequently to a higher

Table 1 Comparison of different $E$. coli hosts for tyrosinase production

\begin{tabular}{lccc}
\hline Hosts $^{\mathbf{a}}$ & $\boldsymbol{\mu}_{\max }\left(\mathbf{h}^{\mathbf{- 1}}\right)^{\mathbf{b}}$ & $\mathbf{O D}_{\mathbf{6 0 0 m a x}}{ }^{\mathbf{c}}$ & Max. act. $\left(\mathbf{U ~ m}_{\mathbf{~ m}}^{\mathbf{- 1}}\right)^{\mathbf{d}}$ \\
\hline DH5a & $0.26 \pm 0.04$ & $7.7 \pm 0.4$ & $0.44 \pm 0.05$ \\
DH5a + IPTG & $0.27 \pm 0.03$ & $8.0 \pm 0.3$ & $0.44 \pm 0.01$ \\
BLR & $0.60 \pm 0.01$ & $8.9 \pm 0.4$ & $0.03 \pm 0.00$ \\
BLR + IPTG & $0.57 \pm 0.02$ & $7.5 \pm 0.6$ & $0.03 \pm 0.00$ \\
JM109 & $0.60 \pm 0.02$ & $7.4 \pm 0.3$ & $0.03 \pm 0.00$ \\
JM109+IPTG & $0.59 \pm 0.03$ & $7.7 \pm 0.4$ & $0.07 \pm 0.01$
\end{tabular}

${ }^{\text {a }}$. Cells were grown in shake flasks at $37^{\circ} \mathrm{C}$ with or without $1 \mathrm{mM}$ IPTG induction at the early growth phase $\left(\mathrm{OD}_{600} \approx 0.6\right)$.

b. $\mu_{\text {max }}$ : the maximal growth rate.

c. $\mathrm{OD}_{600 \mathrm{max}}$ : the maximal optical density measured at $600 \mathrm{~nm}$.

d. Max. act.: the maximal volumetric activity of tyrosinase in units per $\mathrm{mL}$ of culture broth. total tyrosinase activity. Thus, sufficient oxygen supply is advantageous for tyrosinase production. These data demonstrated that tyrosinase production is associated with cell density: the volumetric tyrosinase activity increased in the same manner as the exponential growth of the cells (Figure 1).

\section{Influence of induction stage on tyrosinase production}

The influence of different concentrations of IPTG on cell growth and tyrosinase production was first tested. It was found that the biomass, the growth rate and the total tyrosinase activities were not influenced significantly by the tested IPTG concentrations between $0.1 \mathrm{mM}$ and $1.0 \mathrm{mM}$ (data not shown).

As mentioned above, overexpression of a protein places an additional metabolic burden on the energy of the cells, carbon and amino acid pools, which may result in reduced cell growth. This can be avoided by employing inducible expression systems. The culture conditions at the time of induction can affect the efficiency of induction. In this study, IPTG induction was initiated at different growth stages, i.e. in the early-, mid- or late-exponential growth phase (Figure 2 and Table 2). Figure 2 shows that early induction led to immediate tyrosinase production within $6 \mathrm{~h}$ of cultivation. However, the tyrosinase band on the SDSPAG disappeared after $12 \mathrm{~h}$ of cultivation, indicating the enzyme was either degraded or diluted with the increase of biomass. Induction at the mid-growth phase resulted in the production of tyrosinase after $2 \mathrm{~h}$ induction. The tyrosinase levels increased with cultivation time and reached the maximum at the end of cultivation (24 h) (Figure 2). Induction at the late-growth phase gave a high level of tyrosinase already after $4 \mathrm{~h}$ of induction (i.e. after $12 \mathrm{~h}$ of growth) and prolonged cultivation did not cause significant increase of the enzyme (Figure 2). The best stage for induction was thus the late-exponential growth phase: even though the growth rate and maximal biomass were similar to those of induction at mid-growth stage, the total tyrosinase activity was about 1.6 fold higher than in the latter case (Table 2). The early induction led to the lowest growth rate and lowest maximal biomass. The total tyrosinase activity was also 10-15 fold lower than that at mid- or late-growth phase induction (Table 2).

Investigation of the induction stage is an important parameter for the development of the optimized protein production, especially when a strong promoter system is used, which was the case in this study. Induction of a strong promoter often leads to a sudden burst of protein synthesis which may inhibit cell growth due to a severe metabolic burden [43]. This can be well demonstrated by the results obtained here: early induction led to a reduced growth rate (Table 2). 


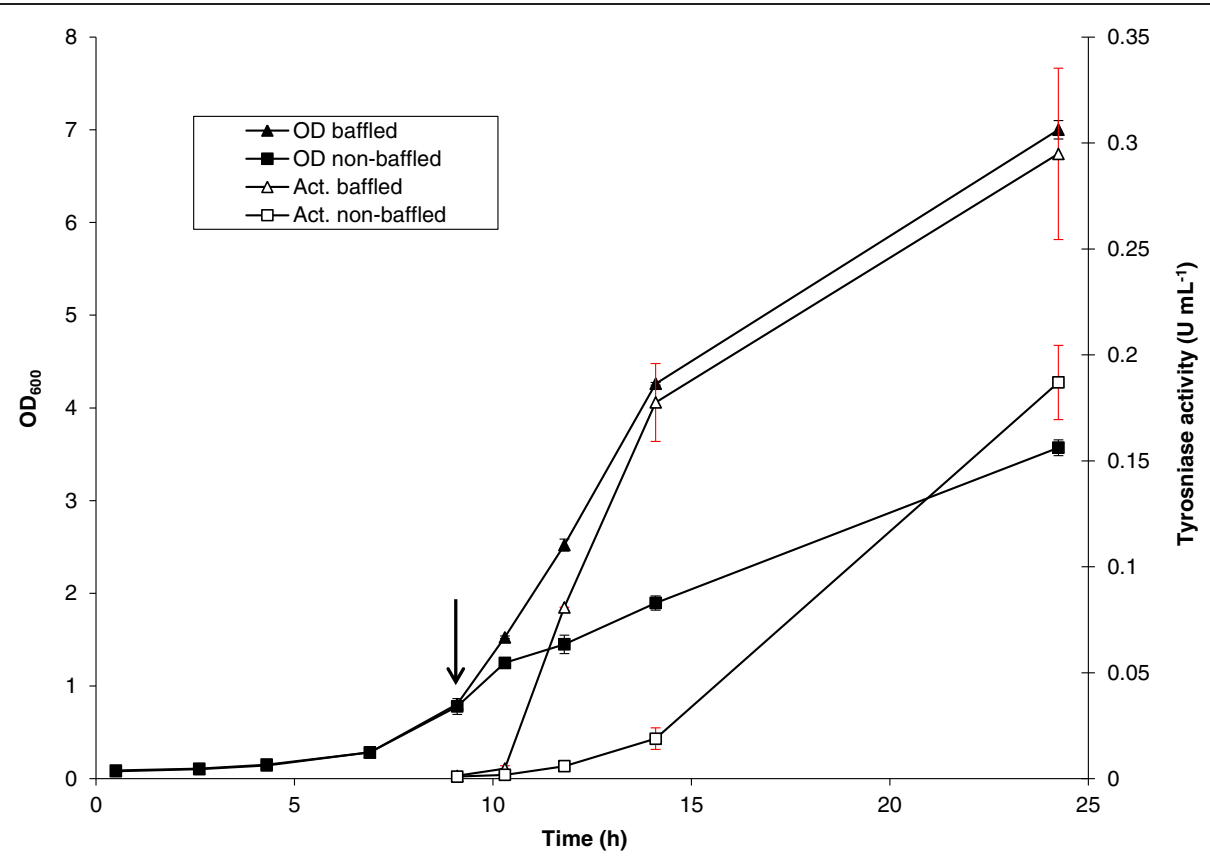

Figure 1 Time course of cell growth and tyrosinase activity influenced by $\mathbf{O}_{\mathbf{2}}$. The freshly transformed E. coli JM109 (pMFvpt) recombinant cells were grown in shake flasks at $37^{\circ} \mathrm{C}$ and induced at the early exponential growth phase with $1.0 \mathrm{mM}$ IPTG. The arrow indicates the time of IPTG induction. Data points are the averages of the results of duplicate measurements.

\section{Influence of temperature on tyrosinase production}

For high cell density cultures, temperature control is very important due to considerable heat release at high viscosity. Temperature should support cell growth as well as product formation. In this study, time courses at temperatures of $25,30,32$, and $37^{\circ} \mathrm{C}$ were followed. Decreasing the temperature from $37^{\circ} \mathrm{C}$ to $25^{\circ} \mathrm{C}$ led to decrease of grow rate, as expected. At $25^{\circ} \mathrm{C}$ only about half of the growth rate reached at $37^{\circ} \mathrm{C}$ was achieved (Table 3). The impact of the incubation temperature on

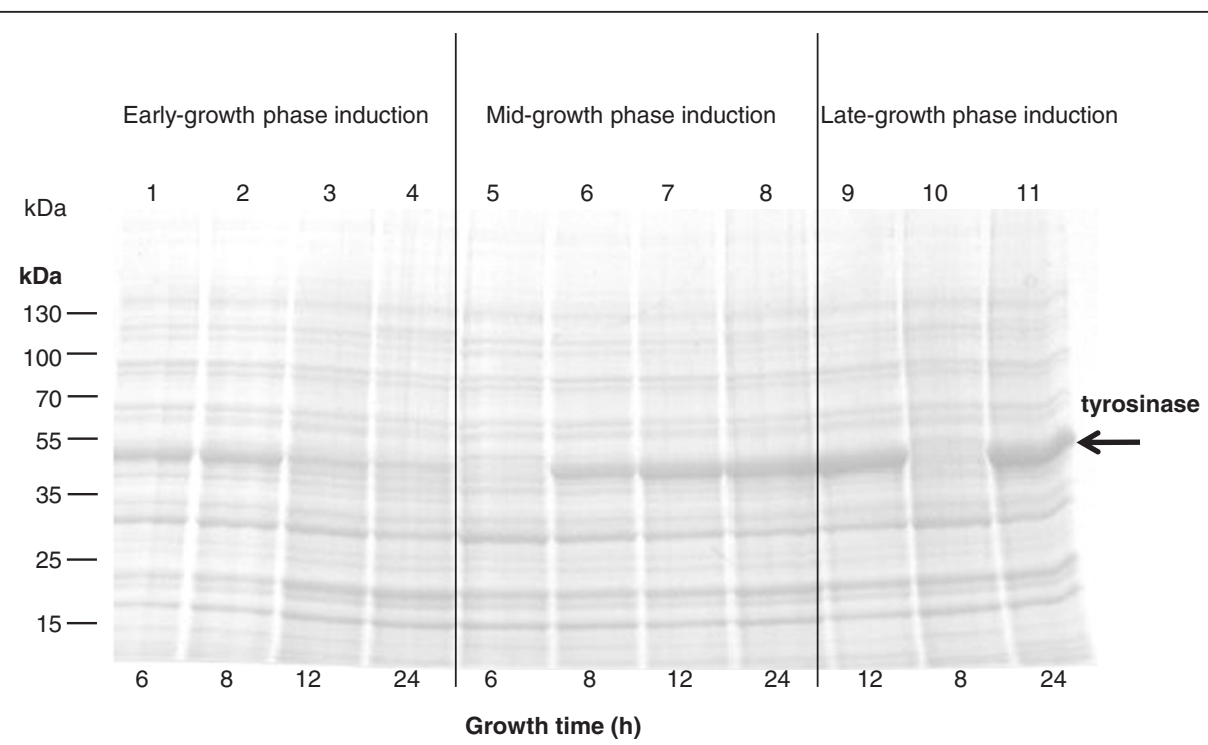

Figure 2 Influence of induction stages on tyrosinase production. The freshly transformed E. coli JM109 (pMFvpt) recombinant cells were grown in shake flasks at $37^{\circ} \mathrm{C}$ and induced with $1 \mathrm{mM} \mathrm{IPTG}$ at the early (from the beginning of the cultivation), mid ( $6 \mathrm{~h}$ cultivation) or late (8 $\mathrm{h}$ cultivation) growth phase. The extracts of E. coli JM109 (pMFvpt) were prepared and analyzed by SDS-PAGE. Lanes 1-4, samples from induction at the beginning of the cultivation; Lanes 5-8, samples from induction at mid-growth phase; lanes 9-11, samples from induction at late-growth phase. The arrow indicates the position of tyrosinase in the gel. Molecular weight standards are shown on the left. 
Table 2 Comparison of induction stages for tyrosinase production

\begin{tabular}{lccc}
\hline Growth stage ${ }^{\mathbf{a}}$ & $\left.\boldsymbol{\mu}_{\max } \mathbf{( h}^{\mathbf{- 1}}\right)^{\mathbf{b}}$ & $\mathbf{O D}_{\text {600max }}{ }^{\mathbf{c}}$ & Max. act. $\left(\mathbf{U ~ m L}^{-\mathbf{1}}\right)^{\mathbf{d}}$ \\
\hline Early & $0.39 \pm 0.03$ & $7.2 \pm 0.5$ & $0.05 \pm 0.01$ \\
Mid & $0.57 \pm 0.02$ & $8.4 \pm 0.5$ & $0.47 \pm 0.07$ \\
Late & $0.57 \pm 0.03$ & $8.9 \pm 1.0$ & $0.76 \pm 0.06$
\end{tabular}

a Cells were induced with $1 \mathrm{mM}$ IPTG at the early-, mid- or late- growth phase. b. $\mu_{\text {max }}$ the maximal growth rate.

c. $\mathrm{OD}_{600 \mathrm{max}}$ : the maximal optical density measured at $600 \mathrm{~nm}$.

d. Max. act.: the maximal volumetric activity of tyrosinase in units per $\mathrm{mL}$ of culture broth.

JM109 (pMFvpt) cells were grown in shake flasks at $37^{\circ} \mathrm{C}$.

tyrosinase production could also be clearly seen in Table 3. The best tyrosinase production $\left(0.76 \mathrm{U} \mathrm{mL}^{-1}\right)$ was observed at $32^{\circ} \mathrm{C}$. An increase from $32^{\circ} \mathrm{C}$ to $37^{\circ} \mathrm{C}$ resulted in about 2 fold lower enzyme production, while the shift of incubation temperature from $32^{\circ} \mathrm{C}$ to $30^{\circ} \mathrm{C}$ reduced the enzyme production 3.5 fold (Table 3 ). Decrease of temperature from $32^{\circ} \mathrm{C}$ to $25^{\circ} \mathrm{C}$ caused a more than 5 fold reduction of the total enzyme yield. Time course experiments at different temperatures allowed to quickly optimize expression conditions for high level production of tyrosinase.

\section{Tyrosinase production using fed-batch cultivation}

Different processes focusing on nutrient feeding strategies have been developed to grow cells to high cell densities and to overproduce proteins [44]. The most important function of such strategies is to prevent overfeeding, as inhibitory concentrations of the feed components can accumulate in the fermenter, or underfeeding, by which the organism is starved for essential nutrients. The method of choice depends on many different factors, including the metabolism of the organism, the potential for production of inhibitory substrates and induction conditions. Batch [45], continuous [46], and a variety of fed-batch processes [39,47] have been reported for growing cells to high densities. Among these, fed-batch is the most commonly used method to produce recombinant proteins [44].

Table 3 Influence of culture temperature on tyrosinase production

\begin{tabular}{lccc}
\hline Temperature & $\boldsymbol{\mu}_{\max }\left(\mathbf{h}^{-1}\right)^{\mathbf{a}}$ & $\mathbf{O D}_{\mathbf{6 0 0 m a x}}{ }^{\mathbf{b}}$ & Max. act. $\left(\mathbf{U} \mathbf{~ m L}^{-\mathbf{1}}\right)^{\mathbf{c}}$ \\
\hline $25\left({ }^{\circ} \mathrm{C}\right)$ & $0.31 \pm 0.02$ & $7.8 \pm 0.9$ & $0.12 \pm 0.03$ \\
$30\left({ }^{\circ} \mathrm{C}\right)$ & $0.52 \pm 0.02$ & $8.0 \pm 0.7$ & $0.22 \pm 0.03$ \\
$32\left({ }^{\circ} \mathrm{C}\right)$ & $0.60 \pm 0.03$ & $10.2 \pm 0.9$ & $0.76 \pm 0.06$ \\
$37\left({ }^{\circ} \mathrm{C}\right)$ & $0.66 \pm 0.02$ & $10.8 \pm 1.0$ & $0.36 \pm 0.05$ \\
\hline
\end{tabular}

a. $\mu_{\max }$ : the maximal growth rate.

b. $\mathrm{OD}_{600 \mathrm{max}}$ : the maximal optical density measured at $600 \mathrm{~nm}$.

c. Max. act.: the maximal volumetric activity of tyrosinase in units per $\mathrm{mL}$ of culture broth.

The freshly transformed JM109 (pMFvpt) cells were grown in shake flasks at $25,30,32$ or $37^{\circ} \mathrm{C}$ and induced at the early-exponential growth phase $\left(\mathrm{OD}_{600} \approx 1.1\right)$ with $1.0 \mathrm{mM}$ IPTG.
Using exponential feeding would allow the culture to be kept in an extended exponential growth phase even at high cell density. In our case, production of recombinant tyrosinase is correlated with cell density during the growth (Figure 1). It was therefore decided to apply an exponential forward-feed strategy. Experiments were performed in a $1 \mathrm{~L}$ controlled bioreactor. Cells were first grown in batch medium at the optimal temperature of $32^{\circ} \mathrm{C}$ with glycerol as the carbon source. Batch growth, which preceded the fed-batch cultivation, resulted in a maximum growth rate of $0.4 \mathrm{~h}^{-1}$. Feeding started after $16 \mathrm{~h}$ of batch growth when glycerol was completely consumed (Figure 3A). The exponential mass-flow rate of glycerol in the feeding solution was set at $0.3 \mathrm{~h}^{-1}$. When $\mathrm{OD}_{600}$ reached about 34 (at $22 \mathrm{~h}$ of cultivation), cells were induced with $1.25 \mathrm{mM}$ IPTG, and tyrosinase activity was followed with time. Figure $3 \mathrm{~B}$ shows the growth profile and the total tyrosinase activity as a function of time during the fed-batch phase. The culture appeared to grow with a growth rate of $0.28 \mathrm{~h}^{-1}$. The difference between the feeding rate of $0.3 \mathrm{~h}^{-1}$ and the growth rate of $0.28 \mathrm{~h}^{-1}$ can be explained by the fact that glycerol was not only used for growth, but also for cell maintenance. It was also observed that when the feeding was stopped manually on purpose, the dissolved oxygen concentration instantly increased sharply (Figure 3A). This suggests that during the fed-batch mode the growing cells immediately consumed any glycerol that was added to the culture. The exponential growth phase lasted until the cell density reached $37 \mathrm{~g} \mathrm{~L}^{-1}\left(\mathrm{OD}_{600}\right.$ of 102) after $28 \mathrm{~h}$ of incubation, after which there was very little change in the cell density (Figure 3B). This was mainly due to the limitation of the bioreactor capacity: the dissolved oxygen could not be further increased even by using pure oxygen. Production of active tyrosinase increased steadily from 0 to $13 \mathrm{U} \mathrm{mL}^{-1}$ after $6 \mathrm{~h}$ induction, and increased only slightly from 13 to $13.6 \mathrm{U} \mathrm{mL}^{-1}$ with the prolongation from 28 to $40 \mathrm{~h}$ (Figure 3B). The obtained activity of $13 \mathrm{U} \mathrm{mL}^{-1}$ corresponded to $2.89 \mathrm{~g} \mathrm{~L}^{-1}$ of active tyrosinase in the culture based on our previous findings that the specific activity of purified tyrosinase is about $4.5 \mathrm{U} \mathrm{mg}^{-1}$ [38]. Compared with the previously reported process where $1 \mathrm{~g} \mathrm{~L}^{-1}$ tyrosinase was produced in 6 days [36], the process established in this study allowed production of almost $3 \mathrm{~g} \mathrm{~L}^{-1}$ active tyrosinase in 28 hours, which is about 15 fold higher with respect to process productivity.

The optimal setting of the value for the feeding rate plays an important role in obtaining long-lasting fedbatch growth of $E$. coli cells. The feeding rate should maintain optimum cellular health, which is required to overcome the metabolic stress associated with recombinant protein expression [48]. A too high feeding rate would lead to accumulation of glycerol very early during 


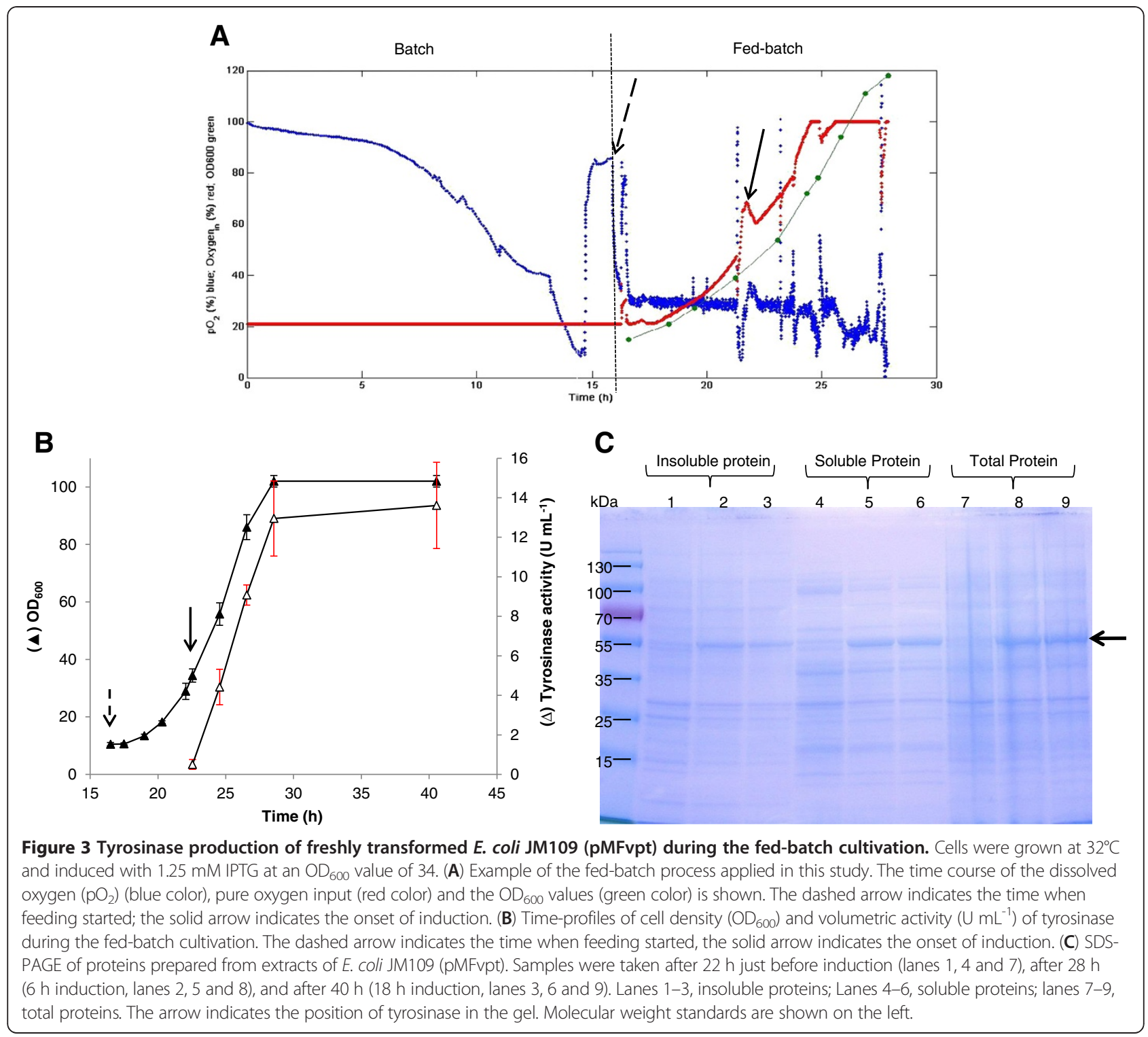

the fed-batch, a premature slowdown of growth and, therefore, a short cultivation time. A too low feeding rate may lead to prolonged cultivation time before reaching high cell density, thus resulting in a low process productivity. It has been reported that a specific growth rate of $0.3 \mathrm{~h}^{-1}$ prevents several negative effects, such as increased cell lysis, higher levels of endotoxin accumulation and membrane stiffness, which are characteristics of cells at low specific growth rates $[49,50]$. An exponential feeding strategy to maintain a specific growth rate of $0.3 \mathrm{~h}^{-1}$ was therefore used in this study. A feeding rate of $0.4 \mathrm{~h}^{-1}$ was also tested and resulted in overfeeding and foaming problems (data not shown).

The tyrosinase content was further analyzed by SDSPAGE (Figure 3C). The soluble tyrosinase was clearly predominant in the total soluble protein fraction after
$6 \mathrm{~h}$ of induction and was maintained for at least another $12 \mathrm{~h}$ (Figure 3C). Compared to the batch cultures in shake flasks, the fed-batch approach resulted in an improvement of 17 fold of the yield of active tyrosinase from $0.17 \mathrm{~g} \mathrm{~L}^{-1}$ to $2.89 \mathrm{~g} \mathrm{~L}^{-1}$, and 15 fold of the overall volumetric productivity from $31.7 \mathrm{mU} \mathrm{L}^{-1} \mathrm{~h}^{-1}$ (corresponding to $7.1 \mathrm{mg} \mathrm{L}^{-1} \mathrm{~h}^{-1}$ ) to $464.3 \mathrm{mU} \mathrm{L}^{-1} \mathrm{~h}^{-1}$ (corresponding to $103.2 \mathrm{mg} \mathrm{L}^{-1} \mathrm{~h}^{-1}$ ) (Table 4). These results demonstrate that it was possible to obtain a high tyrosinase production even at high cell densities.

No significant change in activity was observed even $12 \mathrm{~h}$ after the highest cell density in the fed batch experiment was reached (Figure 3B). Previously it has been observed that loss of tyrosinase activity due to proteolytic activity in recombinant Streptomyces was detected during all phases of batch culture, especially in stationary phase [51]. When 
Table 4 Comparison of tyrosinase production in batch and fed-batch cultures

\begin{tabular}{ccccccc}
\hline & $\begin{array}{c}\text { Cultivation } \\
\text { time }(\mathbf{h})\end{array}$ & $\mathrm{OD}_{\max }$ & $\begin{array}{c}\text { Vol. activity of } \\
\text { tyrosinase }\left(\mathbf{U ~ m L}^{-1}\right)\end{array}$ & $\begin{array}{c}\text { Yield of } \\
\text { tyrosinase }\left(\mathbf{g ~ L}^{-1}\right)\end{array}$ & $\begin{array}{c}\text { Vol. productivity of } \\
\text { tyrosinase }\left(\mathbf{m g ~ L}^{-1} \mathbf{h}^{-1}\right)\end{array}$ & $\begin{array}{c}\text { Vol. act. of tyrosinase per } \\
\text { time }\left(\mathbf{m U ~ m ~}^{-1} \mathbf{h}^{-1}\right)\end{array}$ \\
\hline $\begin{array}{c}\text { Shake flask } \\
\text { (Batch) }\end{array}$ & 24 & $10.0 \pm 0.9$ & $0.76 \pm 0.06$ & $0.17 \pm 0.01$ & $7.1 \pm 0.4$ & $31.7 \pm 2.5$ \\
$\begin{array}{c}\text { Bioreactor } \\
\text { (Fed-batch) }\end{array}$ & 28 & $102.0 \pm 2.0$ & $13.00 \pm 2.18$ & $2.89 \pm 0.48$ & $103.2 \pm 17.1$ & $464.3 \pm 77.8$ \\
\hline
\end{tabular}

the tyrosinase of $S$. antibioticus was expressed in E. coli, the activity of intracellular tyrosinase decreased with time [52]. The results obtained in this study suggest that $V$. spinosum tyrosinase produced in E. coli is stable, at least during the 40 hour cultivation tested here. This will undoubtedly simplify the purification of this enzyme.

\section{Stability of tyrosinase expression}

During this study, we encountered loss of tyrosinase gene expression: when the starting inoculum was taken from a single colony on a plate which was stored at $4^{\circ} \mathrm{C}$ for more than $24 \mathrm{~h}$, or from $-80^{\circ} \mathrm{C}$ frozen stock, the recombinant cells lost the ability to produce tyrosinase under the tested conditions (Figure 4A). The cells were analyzed by SDS-PAGE and at the same time used for plasmid preparation. No tyrosinase band could be detected on the SDS-Gel (Figure 4B), even though resistance towards ampicillin conferred by the plasmid pMFvpt was detected in more than 95\% of all cells (data not shown). For comparison, the purified plasmid was transformed freshly into E. coli JM109 cells and the resulting recombinant was used for tyrosinase production. In this case, tyrosinase production and activity were restored (Figures $4 \mathrm{~A}$ and $4 \mathrm{~B}$ ). We have no proven

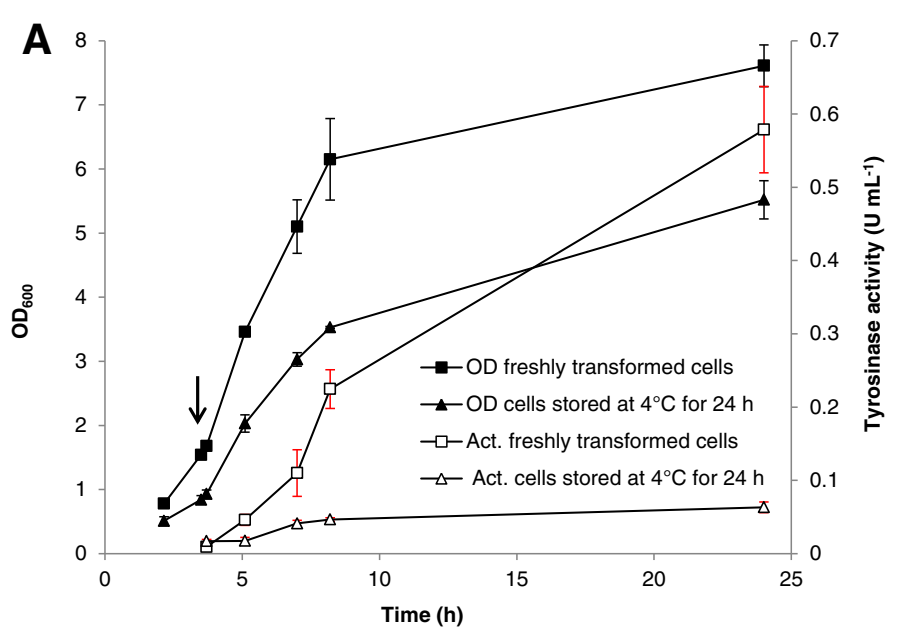

B

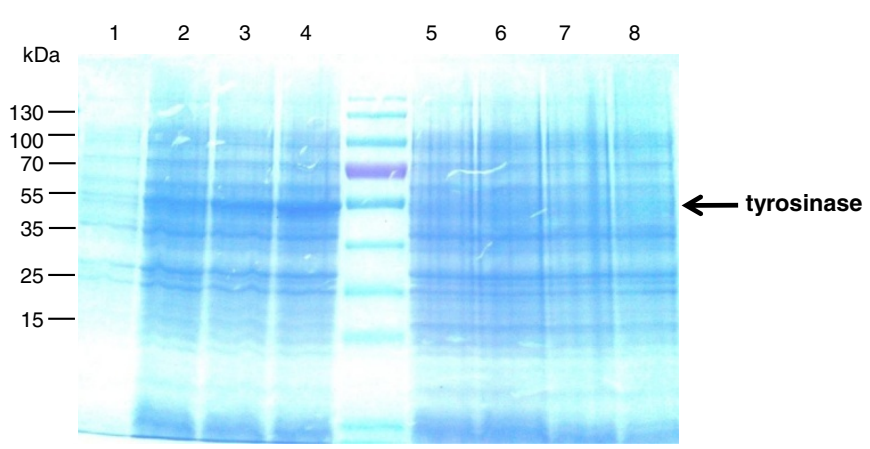

Figure 4 Loss of tyrosinase expression in E. coli JM109 (pMFvpt). The cells were grown in shake flasks at $32^{\circ} \mathrm{C}$ and induced with $1.0 \mathrm{mM}$ IPTG. (A) Time profile of cell growth and tyrosinase activity of E. coli JM109 freshly transformed with pMFvpt and E. coli JM109 (pMFvpt) stored at $4^{\circ} \mathrm{C}$ for $24 \mathrm{~h}$. The arrow indicates the onset of IPTG induction. (B) SDS-PAGE of total proteins prepared from E. coli JM109 (pMFvpt) cells. Samples were taken after $4 \mathrm{~h}$ just before induction (lanes 1 and 5), after $7 \mathrm{~h} \mathrm{(} 3 \mathrm{~h}$ induction, lanes 2 and 6), after $8 \mathrm{~h} \mathrm{(4} \mathrm{h} \mathrm{induction,} \mathrm{lanes} 3$ and 7), and after $24 \mathrm{~h}$ (20 h induction, lanes 4 and 8). Lanes 1-4, samples of freshly transformed E. coli JM109 (pMFvpt); Lanes 5-8, samples of 24 h old E. coli JM109 (pMFvpt). The arrow indicates the position of tyrosinase in the gel. Molecular weight standards are shown on the left. 
explanation for this phenomenon. It is possible that the tyrosinase gene on the plasmid pMFvpt was lost. In order to obtain good expression of tyrosinase, the plasmid pMFvpt was always transformed freshly into $E$. coli JM109 cells during the entire study.

\section{Conclusion}

In conclusion, we have successfully expressed and produced gram quantities per liter of active tyrosinase in recombinant $E$. coli by optimizing the expression conditions and fed-batch cultivation strategy. Fed-batch feeding was performed by exponential forward-feed mode which has the potential of reducing the fermentation time and thus cost. The recommended fermentation protocol is summarized in Table 5. In this protocol, exponential feed of substrate helped to increase the exponential phase of growth, thereby allowing a high cell density of $37 \mathrm{~g} \mathrm{~L}^{-1}$. This in turn helped in achieving a final concentration of about $3 \mathrm{~g} \mathrm{~L}^{-1}$ of soluble, active recombinant tyrosinase, which is 17 fold higher than that achieved in shake flasks. A specific tyrosinase production rate of $103 \mathrm{mg} \mathrm{L}^{-1} \mathrm{~h}^{-1}$ and a maximum volumetric activity of $464 \mathrm{mU} \mathrm{L}^{-1} \mathrm{~h}^{-1}$ were achieved in this study. These levels have not been reported previously.

Since tyrosinase has potential for a broad range of applications, it is expected that an efficient production process will facilitate its actual usage. This work demonstrated an effective process of a bacterial tyrosinase production in the laboratory scale. Further improvement such as in the yield of active enzyme and validation of the scalability of the process are still needed.

\section{Methods}

\section{Bacterial strains and plasmid}

E. coli DH5 $\alpha$ (E. coli Genetic Stock Center), BLR (Novagen) and JM109 (New England BioLabs) were tested as hosts for tyrosinase production. The plasmid pMFvpt, which contains the gene encoding the cytoplasmic full- length tyrosinase $(53.5 \mathrm{kDa})$ of $V$. spinosum, was used to produce the recombinant tyrosinase [38].

\section{Materials}

All chemicals used were purchased from Sigma-Aldrich (Buchs Switzerland) unless otherwise stated.

\section{Media}

Luria broth (LB), $5 \mathrm{~g}$ yeast extract, $10 \mathrm{~g}$ tryptone, and $5 \mathrm{~g} \mathrm{NaCl}$ per liter, was used for pre-inoculum cultures. It was supplemented with ampicillin to a final concentration of $0.1 \mathrm{mg} \mathrm{mL}^{-1}$.

The medium for batch cultures in shake flasks contained ( $\left.\mathrm{g} \mathrm{L}^{-1}\right)$ : glycerol 10, NZ-amine 5, $\left(\mathrm{NH}_{4}\right)_{2} \mathrm{HPO}_{4}$ 4, $\mathrm{KH}_{2} \mathrm{PO}_{4} 5, \mathrm{~K}_{2} \mathrm{HPO}_{4} 7.4, \mathrm{MgSO}_{4}$ * $7 \mathrm{H}_{2} \mathrm{O} 1.2$, thiamine $\mathrm{HCl} 0.015$, ampicillin 0.1 and $10 \mathrm{~mL}$ of trace element solution (TES). TES contained $\left(\mathrm{g} \mathrm{l}^{-1}\right): \mathrm{CaCl}_{2} * 2 \mathrm{H}_{2} \mathrm{O} 5$, $\mathrm{FeCl}_{3} 4 \mathrm{H}_{2} \mathrm{O}$ 7, $\mathrm{Zn}\left(\mathrm{CH}_{3} \mathrm{COO}\right)_{2}$ "2 $2 \mathrm{H}_{2} \mathrm{O}$ 1.3, $\mathrm{MnCl}_{2}$ " $4 \mathrm{H}_{2} \mathrm{O}$ 1.5, $\mathrm{CoCl}_{2}$ * $6 \mathrm{H}_{2} \mathrm{O}$ 0.25, $\mathrm{H}_{3} \mathrm{BO}_{3} 0.3, \mathrm{Na}_{2} \mathrm{MoO}_{4}$ * $2 \mathrm{H}_{2} \mathrm{O} 0.25$, ethylenediaminetetraacetic acid (EDTA) 1.25 and $10 \mathrm{~mL}$ of concentrated $\mathrm{HCl}$. Cells were induced with isopropyl $\beta$-D-1-thiogalactopyranoside (IPTG) under the conditions described in the Results section. Thiamine, ampicillin, TES and IPTG were filter-sterilized $(0.2 \mu \mathrm{m}$, Millipore).

The medium for batch cultures in the bioreactor contained ( $\left.\mathrm{g} \mathrm{L}^{-1}\right)$ : glycerol 20, NZ-Amine 5, $\left(\mathrm{NH}_{4}\right)_{2} \mathrm{HPO}_{4} 4$, $\mathrm{KH}_{2} \mathrm{PO}_{4} \quad 13.3, \quad\left(\mathrm{NH}_{4}\right)_{2} \mathrm{SO}_{4} \quad 1, \quad \mathrm{MgSO}_{4} \quad$ " $7 \mathrm{H}_{2} \mathrm{O} \quad 1.2$, thiamine $\mathrm{HCl} 0.015$, ampicillin 0.1 and $10 \mathrm{ml}$ of TES containing additional $0.15 \mathrm{~g} \mathrm{l}^{-1} \mathrm{CuCl}_{2} * 4 \mathrm{H}_{2} \mathrm{O}$. The feed medium contained $\left(\mathrm{g} \mathrm{L}^{-1}\right)$ : glycerol 500, NZ-Amine 100, $\mathrm{MgSO}_{4} * 7 \mathrm{H}_{2} \mathrm{O} 13.5$ and $\left(\mathrm{NH}_{4}\right)_{2} \mathrm{SO}_{4} 50$.

\section{Cultivation conditions}

Plasmid pMFvpt was transformed into E. coli competent cells by chemical $\mathrm{CaCl}_{2}$ method [53]. The freshly transformed cells were used to inoculate a $10 \mathrm{~mL} \mathrm{LB}$ pre-culture in a $50 \mathrm{~mL}$ flask. The cells were incubated at $37^{\circ} \mathrm{C}$ and $150 \mathrm{rpm}$ overnight. The pre-culture was then

Table 5 Summary of the optimized process used in this study for tyrosinase production

\begin{tabular}{lr}
\hline Parameters & \multicolumn{1}{c}{ Tyrosinase production } \\
\hline Strain & JM109 (pMFvpt) \\
Medium & Minimal medium containing glycerol and NZ-amine \\
Temperature $\left({ }^{\circ} \mathrm{C}\right)$ & 32 \\
$\mathrm{pH}$ & 6.9 \\
Dissolved oxygen $(\%)$ & 30 \\
Cultivation & Fed-batch culture with exponential feeding \\
Feeding medium & Glycerol and NZ-amine \\
Feeding rate $\left(\mathrm{h}^{-1}\right)$ & 0.3 \\
Induction stage & At OD $\mathrm{D}_{600}$ value of $30-40$ \\
Harvest & End of the exponential growth \\
\hline
\end{tabular}


used to inoculate $200 \mathrm{~mL}$ of batch medium in a $1 \mathrm{~L}$ shake flask with a dilution of 1:20 (v/v). It was incubated at $150 \mathrm{rpm}$ and different temperatures as described in the Results section. Growth and product formation were monitored by periodically taking samples, from which cells were harvested by centrifugation at $12^{\prime} 000 \mathrm{~g}$ for 2 min at $4^{\circ} \mathrm{C}$. A final $\mathrm{OD}_{600}$ of $7-8$ was routinely achieved.

For the experiment of testing oxygen influence, $1 \mathrm{~L}$ baffled (with 4 baffles indented into the base, Schott Duran) and non-baffled Erlenmeyer flasks (Schott Duran) were used.

For bioreactor experiments, the cells freshly transformed with plasmid pMFvpt were grown in shake flasks in LB medium for $12 \mathrm{~h}$ at $37^{\circ} \mathrm{C}$ and $150 \mathrm{rpm}$. The bioreactors were inoculated with a 1:20 (v/v) dilution of the preculture. The cells were grown in a $600 \mathrm{~mL}$ (total volume 1.4 L) computer controlled bioreactor (Infors AG, Bottmingen, $\mathrm{CH}$ ) equipped with standard control units. Tyrosinase expression was induced by $1.25 \mathrm{mM}$ IPTG. The $\mathrm{pH}$ was maintained at $6.90 \pm 0.05$ by proportional-integral (PI) controlled addition of $4 \mathrm{M} \mathrm{NaOH} / 28 \%$ $\mathrm{NH}_{4} \mathrm{OH} 1 / 1(\mathrm{v} / \mathrm{v})$, and the temperature was set to $32.0^{\circ} \mathrm{C} \pm 0.5^{\circ} \mathrm{C}$. In order to avoid oxygen limitation the dissolved oxygen (DO) level was stabilized to above $30 \%$ saturation by stirrer speed and aeration rate control. If necessary, 1'200 rpm (rotation per minute) and 1-2 vvm (volume per volume per minute) of air enriched with pure oxygen by a PI controller were applied to keep the DO above $30 \%$. Foaming was suppressed by addition of 10-100 $\mu \mathrm{l}$ antifoam suspension (PPG 2000). Feeding was started after the batch ended, as indicated by a sudden increase of the DO-signal. The feed medium was fed exponentially into the fermenter using a variable speed peristaltic pump.

\section{Tyrosinase activity}

Samples were diluted to $\mathrm{OD}_{600}=1$, and $1 \mathrm{ml}$ was centrifuged at $12^{\prime} 000 \mathrm{~g}$ for $2 \mathrm{~min}$. The pellet was washed once with $1 \mathrm{ml}$ and resuspended in $0.5 \mathrm{ml}$ $0.1 \mathrm{M}$ Tris- $\mathrm{HCl}(\mathrm{pH}$ 8). The suspension was sonicated for $10 \mathrm{~s}$ with $10 \%$ power (Branson Ultrasonics Corp., Danbury, CT, USA), and centrifuged at 12 '000 $\mathrm{g}$ for $2 \mathrm{~min}$. The supernatant was analyzed for tyrosinase activity by measuring dopachrome formation [38,54]. One unit is defined as $1 \mu \mathrm{mol}$ dopachrome formed per minute. The protein concentrations in the supernatant were quantified using the Bradford method.

\section{SDS-PAGE}

SDS-PAGE analysis was performed using standard methods [55] and gels were subsequently stained with Coomassie brilliant blue. The PageRuler plus prestained protein ladder (Fermentas, $\mathrm{GmbH}$ ) was used as a marker in all gels.

\section{Cell growth}

The cell growth was followed by measuring the optical density at $600 \mathrm{~nm}$ (Spectronic Genesys 6, Thermo Electron Corp., UK) and correlated to cell dry weight (cdw) with a ratio $\mathrm{cdw} / \mathrm{OD}=0.36$.

\section{Reproducibility}

All measurements for growth and tyrosinase activity were performed at least in duplicates. The data presented in this report are the average values.

\section{Competing interests}

The authors declare that they have no competing interests.

\section{Authors' contributions}

QR participated in the design and coordination of the study, and drafted the manuscript. $\mathrm{BH}$ participated in the design of the fed-batch study and performed the batch and fed-batch experiments. MF carried out the construction of different E. coli recombinants. LTM conceived the study and helped to draft the manuscript. All authors read and approved the final manuscript.

\section{Acknowledgements}

We thank Dr. Renate Reiss for critically reading the manuscript.

Received: 24 September 2012 Accepted: 20 February 2013 Published: 27 February 2013

\section{References}

1. Fairhead M, Thöny-Meyer L: Bacterial tyrosinases: old enzymes with new relevance to biotechnology. New Biotechnol 2012, 29(2):183-191.

2. Claus H, Decker H: Bacterial tyrosinases. Syst Appl Microbiol 2006, 29(1):3-14.

3. del Marmol $\mathrm{V}$, Beermann F: Tyrosinase and related proteins in mammalian pigmentation. FEBS Lett 1996, 381(3):165-168.

4. Halaouli S, Asther M, Sigoillot JC, Hamdi M, Lomascolo A: Fungal tyrosinases: new prospects in molecular characteristics, bioengineering and biotechnological applications. J App/ Microbiol 2006, 100(2):219-232.

5. Marusek CM, Trobaugh NM, Flurkey WH, Inlow JK: Comparative analysis of polyphenol oxidase from plant and fungal species. J Inorg Biochem 2006, 100(1):108-123.

6. Mayer AM: Polyphenol oxidases in plants and fungi: Going places? A review. Phytochemistry 2006, 67(21):2318-2331.

7. Walker JRL, Ferrar PH: Diphenol oxidases, enzyme-catalysed browning and plant disease resistance. Biotechnol Genet Eng Rev 1998, 15:457-498. Edited by Tombs MP.

8. Jus S, Kokol V, Guebitz GM: Tyrosinase-catalysed coupling of functional molecules onto protein fibres. Enzyme Microb Technol 2008, 42(7):535-542.

9. Jus S, Kokol V, Guebitz GM: Tyrosinase-catalysed coating of wool fibres with different protein-based biomaterials. J Biomat Sci-Polym E 2009, 20(2):253-269.

10. Martorell MM, Pajot HF, Rovati Jl, Figueroa LIC: Optimization of culture medium composition for manganese peroxidase and tyrosinase production during Reactive Black 5 decolourization by the yeast Trichosporon akiyoshidainum. Yeast 2012, 29(3-4):137-144.

11. Seetharam G, Saville BA: L-DOPA production from tyrosinase immobilized on zeolite. Enzyme Microb Technol 2002, 31(6):747-753.

12. Lantto R, Puolanne E, Kruus K, Buchert J, Autio K: Tyrosinase-aided protein cross-linking: Effects on gel formation of chicken breast myofibrils and texture and water-holding of chicken breast meat homogenate gels. J Agric Food Chem 2007, 55(4):1248-1255.

13. Selinheimo E, Autio K, Krijus K, Buchert J: Elucidating the mechanism of laccase and tyrosinase in wheat bread making. J Agric Food Chem 2007, 55(15):6357-6365. 
14. Anghileri A, Lantto R, Kruus K, Arosio C, Freddi G: Tyrosinase-catalyzed grafting of sericin peptides onto chitosan and production of proteinpolysaccharide bioconjugates. J Biotechnol 2007, 127(3):508-519.

15. Freddi G, Anghileri A, Sampaio S, Buchert J, Monti P, Taddei P: Tyrosinasecatalyzed modification of Bombyx mori silk fibroin: Grafting of chitosan under heterogeneous reaction conditions. J Biotechnol 2006, 125(2):281-294.

16. Gu BX, Xu CX, Zhu GP, Liu SQ, Chen LY, Li XS: Tyrosinase immobilization on ZnO Nanorods for phenol detection. J Phys Chem B 2009, 113(1):377-381.

17. Fairhead M, Thöny-Meyer L: Cross-linking and immobilisation of different proteins with recombinant Verrucomicrobium spinosum tyrosinase. J Biotechnol 2010, 150(4):546-551.

18. Lewandowski AT, Small DA, Chen TH, Payne GF, Bentley WE: Tyrosinebased "activatable pro-tag": Enzyme-catalyzed protein capture and release. Biotechnol Bioeng 2006, 93(6):1207-1215.

19. Thalmann CR, Lotzbeyer T: Enzymatic cross-linking of proteins with tyrosinase. Eur Food Res Technol 2002, 214(4):276-281.

20. Monogioudi E, Creusot N, Kruus K, Gruppen H, Buchert J, Mattinen M-L: Cross-linking of beta-casein by Trichoderma reesei tyrosinase and Streptoverticillium mobaraense transglutaminase followed by SEC-MALLS. Food Hydrocolloid 2009, 23(7):2008-2015.

21. Jus S, Stachel I, Schloegl W, Pretzler M, Friess W, Meyer M, BirnerGruenberger R, Guebitz GM: Cross-linking of collagen with laccases and tyrosinases. Mater Sci Eng C-Mater Biol Appl 2011, 31(5):1068-1077.

22. Halaouli S, Asther M, Kruus K, Guo L, Hamdi M, Sigoillot JC, Lomascolo A: Characterization of a new tyrosinase from Pycnoporus species with high potential for food technological applications. J Appl Microbiol 2005, 98(2):332-343.

23. Hearing VJ: Mammalian monophenol monooxygenase (tyrosinase) purification, properties, and reactions catalyzed. Methods Enzymol 1987, 142:154-165.

24. Lerch KLE: Purification and characterization of a tyrosinase from Streptomyces glaucescens. Eur J Biochem 1972, 31(3):427-437.

25. Gasparetti C, Faccio G, Arvas M, Buchert J, Saloheimo M, Kruus K: Discovery of a new tyrosinase-like enzyme family lacking a C-terminally processed domain: production and characterization of an Aspergillus oryzae catechol oxidase. Appl Microbiol Biotechnol 2010, 86(1):213-226.

26. Ito $M$, Inouye K: Catalytic properties of an organic solvent-resistant tyrosinase from Streptomyces sp REN-21 and its high-level production in E. coli. J Biochem 2005, 138(4):355-362.

27. Liu N, Zhang T, Wang YJ, Huang YP, Ou JH, Shen P: A heat inducible tyrosinase with distinct properties from Bacillus thuringiensis. Lett Appl Microbiol 2004, 39(5):407-412.

28. Shuster $V$, Fishman $A$ : Isolation, cloning and characterization of a tyrosinase with improved activity in organic solvents from Bacillus megaterium. J Mol Microbiol Biotechnol 2009, 17(4):188-200.

29. Flurkey A, Cooksey J, Reddy A, Spoonmore K, Rescigno A, Inlow J, Flurkey WH: Enzyme, protein, carbohydrate, and phenolic contaminants in commercial tyrosinase preparations: Potential problems affecting tyrosinase activity and inhibition studies. J Agric Food Chem 2008, 56(12):4760-4768.

30. Sambasiva Rao KRS, Tripathy NK, Mahalaxmi Y, Prakasham RS: Laccase- and peroxidase-free tyrosinase production by isolated microbial strain. J Microbiol Biotechnol 2012, 22(2):207-214.

31. Kumar M, Flurkey WH: Activity, isoenzymes and purity of mushroom tyrosinase in commercial preparations. Phytochemistry 1991, 30(12):3899-3902

32. Chen G-H, Chen W-M, Huang Y-C, Jiang S-T: Expression of recombinant mature human tyrosinase from Escherichia coli and exhibition of its activity without phosphorylation or glycosylation. J Agric Food Chem 2012, 60(11):2838-2843.

33. Kong KH, Park SY, Hong MP, Cho SH: Expression and characterization of human tyrosinase from a bacterial expression system. Comp Biochem Physiol B Biochem Mol Biol 2000, 125(4):563-569.

34. Halaouli S, Record E, Casalot L, Hamdi M, Sigoillot JC, Asther M, Lomascolo A: Cloning and characterization of a tyrosinase gene from the white-rot fungus Pycnoporus sanguineus, and overproduction of the recombinant protein in Aspergillus niger. Appl Microbiol Biotechnol 2006, 70(5):580-589.

35. Kohashi PY, Kumagai T, Matoba Y, Yamamoto A, Maruyama M, Sugiyama M: An efficient method for the overexpression and purification of active tyrosinase from Streptomyces castaneoglobisporus. Protein Expr Purif 2004, 34(2):202-207.

36. Selinheimo E, Saloheimo M, Ahola E, Westerholm-Parvinen A, Kalkkinen N, Buchert J, Kruus K: Production and characterization of a secreted, C-terminally processed tyrosinase from the filamentous fungus Trichoderma reesei. FEBS J 2006, 273(18):4322-4335.

37. Westerholm-Parvinen A, Selinheimo E, Boer H, Kalkkinen N, Mattinen M, Saloheimo M: Expression of the Trichoderma reesei tyrosinase 2 in Pichia pastoris: Isotopic labeling and physicochemical characterization. Protein Expr Purif 2007, 55(1):147-158.

38. Fairhead M, Thöny-Meyer L: Role of the C-terminal extension in a bacterial tyrosinase. FEBS J 2010, 277(9):2083-2095.

39. Riesenberg D, Guthke R: High-cell-density cultivation of microorganisms. Appl Microbiol Biotechnol 1999, 51(4):422-430.

40. Shiloach J, Fass R: Growing E. coli to high cell density - A historical perspective on method development. Biotechnol Adv 2005, 23(5):345-357.

41. Makrides SC: Strategies for achieving high-level expression of genes in Escherichia coli. Microbiol Mol Biol Rev 1996, 60(3):512.

42. Shojaosadati SA, Kolaei SMV, Babaeipour V, Farnoud AM: Recent advances in high cell density cultivation for production of recombinant protein. Iranian J Biotechnol 2008, 6:63-84.

43. Hoffmann F, Weber J, Rinas U: Metabolic adaptation of Escherichia coli during temperature-induced recombinant protein production: 1 . Readjustment of metabolic enzyme synthesis. Biotechnol Bioeng 2002, 80(3):313-319

44. Jana S, Deb JK: Strategies for efficient production of heterologous proteins in Escherichia coli. Appl Microbiol Biotechnol 2005, 67(3):289-298.

45. Castrillo Jl, Kaliterna J, Weusthuis RA, VanDijken JP, Pronk JT: High-celldensity cultivation of yeasts on disaccharides in oxygen-limited batch cultures. Biotechnol Bioeng 1996, 49(6):621-628.

46. Domingues $L$, Lima N, Teixeira JA: Contamination of a high-cell-density continuous bioreactor. Biotechnol Bioeng 2000, 68(5):584-587.

47. Lee SY: High cell-density culture of Escherichia coli. Trends Biotechnol 1996, 14(3):98-105.

48. Sanden AM, Prytz I, Tubulekas I, Forberg C, Le H, Hektor A, Neubauer P, Pragai Z, Harwood C, Ward A, et al: Limiting factors in Escherichia coli fedbatch production of recombinant proteins. Biotechnol Bioeng 2003, 81(2):158-166.

49. Shokri A, Sanden AM, Larsson G: Growth rate-dependent changes in Escherichia coli membrane structure and protein leakage. Appl Microbiol Biotechnol 2002, 58(3):386-392.

50. Shokri A, Sanden AM, Larsson G: Cell and process design for targeting of recombinant protein into the culture medium of Escherichia coli. Appl Microbiol Biotechnol 2003, 60(6):654-664.

51. Gardner AR, Cadman TW: Product deactivation in recombinant streptomyces. Biotechnol Bioeng 1990, 36(3):243-251.

52. Han K, Hong J, Lim HC, Kim CH, Park Y, Cho JM: Tyrosinase production in recombinant $E$. coli containing trp promoter and ubiquitin sequence. Ann NY Acad Sci 1994, 721:30-42.

53. Sambrook J, Russel DW: Molecular Cloning: A Laboratory Manual. 3rd edition. New York: Cold Spring Harbor Laboratory Press; 2001.

54. Fling M, Horowitz NH, Heinemann SF: The isolation and properties of crystalline tyrosinase from Neurospora. J Biol Chem 1963, 238:2045-2053.

55. Laemmli UK: Cleavage of structural proteins during assembly of head of bacteriophage-T4. Nature 1970, 227(5259):680.

doi:10.1186/1472-6750-13-18

Cite this article as: Ren et al:: High level production of tyrosinase in recombinant Escherichia coli. BMC Biotechnology 2013 13:18. 